\title{
FLOW MEDIATED DILATATION IN HYPERTENSIVE PATIENTS AND THEIR SIBLINGS
}

\author{
By \\ El-Sayed Zaki Hatata* and Talal Amer
}

\author{
From \\ Internal Medicine* and Radiodiagnosis Departments \\ Faculty of Medicine, Mansoura University
}

\begin{abstract}
The objective of this study was to evaluate the impact of hypertension on endothelial function. Essential hypertension is an important risk factor for atherosclerosis and endothelial dysfunction is the earliest event in atherogenesis because endothelium play an important role in the modulation of vascular tone by releasing EDRF identified as nitric oxide. We assessed endothelial function in 48 subjects (12 hypertensive and their 12 normotensive siblings with their control groups). B-mode ultrasonography was used to measure the diameter of the brachial artery, endotheliumdependent dilatation was assessed as the change in diameter of the artery during reactive hyperemia (flow mediated dilatation FMD). FMD was less in patients with hypertension $(0.055 \pm 0.035)$ than their control $(0.113 \pm 0.017)(P<0.001)$. Also FMD
\end{abstract} 105 was less in the hypertensive siblings $(0.109 \pm 00.019)$ than their control $(0.19 \pm 0.039) \quad(P<0.001)$. These results indicate that hypertensive patients had decreased FMD of brachial artery during reactive hyperemia, a finding which also present in their siblings although in normotensive range.

\section{INTRODUCTION}

Essential arterial hypertension is an important risk factor for atherosclerosis. There is growing evidence that endothelial dysfunction is the earliest event in atherogenesis and also precedes morphological changes of the arterial wall in hypertensive patients (1). This endothelial dysfunction has been resorted by normalization of the blood pressure (2). Endothelial cells play an important role in the modulation of vascular tone by releasing endothelium-derived relaxing factor (EDRF), identified as nitMANSOURA MEDICAL JOURNAL 
ric oxide (3). Endothelial function is known to be impaired in the early stage of atherosclerosis (4).

One of the most widely recognized methods of determining the endothelial function is the dilatation capability of arteries. Risk factors of atherosclerosis including essential hypertension probably decrease the production and increase the consumption of nitric oxide which play a central role in the vasodilatation (5). Previous studies demonstrated that patients with essential hypertension showed impaired endothelial-dependent vasodilatation of the peripheral resistance arteries. On the other hand, there is only little evidence of the dilatation capability of the systemic conduit arteries in essential hypertensive patients (6).

Endothelial function has been evaluated in human subjects by assessment of the arterial vasodilator response to intra-arterial infusion of acetyl-choline (7). But this method requires arterial catheterization for drug infusion so can't be easily applied.

Celermajer et al. (1992) (4) established a method for non-invasive assessment of endothelial function by ultrasonography where the diameter of brachial artery is measured during reactive hyperemia and after sublingual administration of glyceryl trinitrate, both induce dilatation. The former is mediated by EDRF (endothelium-dependent) whereas the latter acts directly on smooth-muscle cells (endothelial-independent) (8).

\section{Aim of work:-}

The aim of the present work was to evaluate non-invasively whether flow-mediated dilatation (FMD) of the brachial artery is impaired in patients with essential hypertension and to find whether these abnormalities precede clinical manifestations of elevated blood pressure and so could be detected in the normotensive offspring of subjects with essential hypertension.

\section{PATIENTS AND METHODS}

The study encompassed four groups involving a total of 48 subjects classified as follow:-

\section{1- First group (group A):-}

Which include 12 normotensive subjects ( 6 males and 6 females). Their ages and sexes were matched with the hypertensive group (54.25 \pm 2.49 years).

2. Second group (group B):-

Which include 12 hypertensive pa- 
tients ( 6 males and 6 females). Their ages ranged between $50-58$ years ( $54+2.82$ years).

\section{3- Third group (group C):-}

Which include 12 normotensive subjects ( 6 males and 6 females) with age and sex matched to the fourth group (24.08+2.39 years).

4- Fourth group (group D):-

Which include 12 subjects whom comprise the offspring of the hypertensive patients $(6$ males and 6 females). Their ages ranged between $22-28$ years ( $24.91 \pm 1.83$ years).

These subjects were selected from the outpatient clinics of Internal Medicine in Mansoura University Hospitals. The diagnosis of hypertension was defined as a blood pressure of $\geq 140 / 90 \mathrm{mmHg}$ (JNC VI) (systolic/ diastolic) measured in the sitting position on at least three separate occasions. All patients were diagnosed as essential hypertension after exclusion of secondary causes on basis of clinical, laboratory and radiological evaluation.

\section{Exclusion criteria:-}

1- Any patient with secondary hypertension.

2- Any diabetic subject evidenced by history, examination, fasting and post-prandial blood sugar and history of diabetic complications.

3- Any patient with heart disease, valvular lesion, cardiomyopathy or pericardial disease as evidenced by clinical examination and echocardiographic study.

4- Patients with chronic obstructive lung disease evidenced by clinical examination and $\mathrm{x}$-ray study.

5- Patients with pre-existing renal disease-evidenced by urine analysis, serum creatinine.

6- Patients with severe hepatic derangement or hepatorenal disease diagnosed clinically and supported by laboratory tests.

7- Patients with history of cerebral stroke, ischemic heart disease and patients with electrocardiographic evidence of myocardial infarction.

8- Any systemic or blood diseases that affect lipid profile and blood vessels distensability as nephrotic syndrome and collagen diseases.

9- Drug intake, oral pills, vasoactive drugs, antiischemic treatment, chronic non steroidal antiinflammatory drugs.

10- Patients with peripheral arterial diseases.

Steps in patients evaluation:-

A written consent was taken from

MANSOURA MEDICAL JOURNAL 
every subject in this study.

\section{A- Clinical assessment:-}

A thorough history taking and clinical examination were done for all patients and control subjects with stress on:-

- History:-

- Age, sex, duration of hypertension, type of hypertensive treatment, history of neuropathy, retinopathy and history of TIAs, history of angina pectoris, myocardial infarction, heart failure or cerebral stroke, history of drug intake, digitalis, diuretics, history of renal troubles and family history of hypertension and its treatment.

\section{- Examination:-}

General examination:-

- Pulse, blood pressure $(\mathrm{mmHg})$ and calculation of mean blood pressure (mean blood pressure $=$ diastolic $B P+1 / 3$ pulse pressure), jagular venous pulse, arterial pulsation, thyroid swelling, pallor, jaundice and LL oedema.

\section{Local examination:-}

- Leg examination: For arterial pulsation, ischemic and trophic changes.

- Abdominal examination: For signs of hepatic, splenic or renal afVol. 33, No. 3 \& 4 July. \& Oct, 2002 fection.

- Chest and cardiac examination:-

. For pleuro-pulmonary affection.

. For signs of valvular affection.

. For signs of chamber enlargement.

For signs of pericardial diseases.

Investigations:-

All subjects were submitted to routine laboratory tests as: -

- Blood picture.

- Urine analysis: for pyorrhea, proteinuria, casts.

- Serum creatinine.

- Serum Na+. To exclude secon-

- Serum K+. dary hypertension

- Serum albumin: to exclude chronic liver diseases.

- Post-prandial blood sugar: to exclude diabetes mellitus.

Specific investigations:-

- Twelve leads ECG is done for every patient and control subjects.

- 2-D echocardiography and Doppler examination was done to every subject in this study.

- Measurement of FMD of the brachial artery as follow.

Protocol:-

- The study was performed in a 
dark quiet room after the subjects had rested for 15 minutes in the supine position.

- The diameter of the brachial artery was determined by twodimensional ultrasonography (SONACE, 8000-Medison Machine using a linear $7.5 \mathrm{MHz}$ probe).

- The right brachial artery was scanned over a longitudinal section 2 to $5 \mathrm{~cm}$ above the elbow. The diameter was measured at end diastole, which was determined with simultaneous monitoring of the electrocardiogram. The scanned area was marked to measure the same segment of brachial artery repeatedly.

- After the baseline measurement had been obtained, the right forearm was compressed by inflating of a pneumatic tourniquet at a pressure of $250 \mathrm{mmHg}$ for 4 minutes. The second scan was performed at the same level 90 seconds after cuff deflation when the artery was maximally dilated.

- Fifteen minutes later, the diameter of the brachial artery was measured again to confirm that the diameter had returned to baseline level.

\section{RESULTS}

Patients with essential hypertension (group B) has a higher systolic blood pressure than their control group (group A) $(165 \pm 6.74 \mathrm{mmHg})$ versus $(135 \pm 6.74 \mathrm{mmHg})$ with $\mathrm{P}<0.001$, also diastolic blood pressure shows a highly significant elevation in the hypertensive group $(103 \pm 4.97 \mathrm{mmHg}$ ) when compared to the control group $(84.5 \pm 4.98 \mathrm{mmHg})$ with $\mathrm{P}<0.001$ (table I).

The systolic and diastolic blood pressure in the sibling of hypertensive patients (group D) show a highly significant elevation when compared to their healthy control with $P<0.001$ (table I).

The mean blood pressure show a highly significant elevation in the sibling of hypertensive patients $(95 \pm 3.84 \mathrm{mmHg})$ when compared to their healthy control $(82.5 \pm 6.05$ $\mathrm{mmHg}$ ) with $\mathrm{P}<0.001$. The same finding was seen in the hypertensive patients with mean blood pressure $(123 \pm 3.97 \mathrm{mmHg}$ ) when compared to their control $(101 \pm 4.37 \mathrm{mmHg})$ with $\mathrm{P}<0.001$ (table I).

The EDD and ESD show no significant values when comparing the hypertensive patients with their control group with $P=0.87$ also these parameters show non-significant correlation when comparing the sibling of the hy- 
110 FLOW MEDIATED DILATATION IN HYPERTENSIVE etc...

pertensive patients with their control with $\mathrm{P}=0.18$.

The IVS and PW thickness show a highly significant increase when comparing the hypertensive group with their control with $P<0.001$. These parameters show non-significant value when comparing the sibling of hypertensive patients (group D) with their control (group C) (IVS P=0.18, PW $P=1)$.

All hypertensive patients (group B) show diastolic dysfunction with percentage of $100 \%$ while their control (group A) showing diastolic dysfunction in 5 subjects with percentage of $41.7 \%$.

Non of the hypertensive sibling (group D) or their control (group C) show diastolic dysfunction with $0 \%$ (table II).

The flow mediated dilatation (FMD) response was expressed as a change in the end diastolic diameter of the brachial artery during reactive hyperemia compared to the baseline measurement.

The resting brachial diameter was higher in the hypertensive group $(0.41 \pm 0.012 \mathrm{~cm})$ when compared to their control group $(0.37 \pm 0.032 \mathrm{~cm})$ with $P=0.003$. Also the basal brachial diameter was higher in the sibling of hypertensive patients $(0.373 \pm 0.038$ $\mathrm{cm}$ ) when compared to their control healthy subjects $(0.335 \pm 0.027 \mathrm{~cm})$ with $\mathrm{P}=0.009$.

The change in brachial diameter after cuff release (FMD) in hypertensive subjects was less than the control group $(0.055 \pm 0.035)$ versus $(0.113 \pm 0.017)$ with $P<0.001$.

FMD was significantly increase in the group of hypertensive sibling when compared to their basal level with $P<0.001$. Also FMD show a highly significant increase in their control group when compared to their basal level with $P<0.001$ (table III).

The $\%$ of change in brachial diameter which reflects the FMD was significantly lower in the sibling of hypertensive patients with $\%$ of $(0.109+0.019)$ versus $(0.19 \pm 0.039)$ in their control healthy subjects with $\mathrm{P}<0.001$ (table III). 
Table (I): Clinical characteristics of studied groups

\begin{tabular}{|c|c|c|c|c|c|}
\hline & $\begin{array}{l}\text { Control of } \\
\text { bypertensive } \\
\text { (A) }\end{array}$ & $\begin{array}{l}\text { Hypertensive } \\
\text { (B) }\end{array}$ & $\begin{array}{l}\text { Control of } \\
\text { sibling (C) }\end{array}$ & $\begin{array}{l}\text { Sibling of } \\
\text { hypertensive } \\
\text { (D) }\end{array}$ & Test of significance \\
\hline $\begin{array}{l}\text { Age (years) } \\
\text { Mean_SD } \\
\text { Range }\end{array}$ & $\begin{array}{c}54.25 \pm 2.49 \\
(49-58)\end{array}$ & $\begin{array}{l}5+ \pm 2.82 \\
(50-58)\end{array}$ & $\begin{array}{c}24.08 \pm 2.39 \\
(21-29)\end{array}$ & $\begin{array}{c}2+.91 \pm 1.83 \\
(22-28)\end{array}$ & $\begin{array}{l}\text { (A) vs (B). } t=0.23, p=0.82 \\
\text { (C) vs (D). } t=0.95 . p=0.34\end{array}$ \\
\hline $\begin{array}{l}\text { Sex } \\
\text { MF }\end{array}$ & $6 / 6$ & $6 / 6$ & $6 / 6$ & $6 / 6$ & - \\
\hline $\begin{array}{l}\text { DBP }(\mathbf{m m H g}) \\
\text { Mean } \pm S D \\
\text { Range }\end{array}$ & $\begin{array}{c}84.58 \pm 4.98 \\
(80-90)\end{array}$ & $\begin{array}{c}103.33 \pm+.97 \\
(100-110)\end{array}$ & $\begin{array}{c}68.33 \pm 5.77 \\
(60-80)\end{array}$ & $\begin{array}{c}80.41 \pm 3.96 \\
(70-85)\end{array}$ & $\begin{array}{l}\text { (A) vs (B). t=9.27, } p<0.001 \\
\text { (C) vs (D). t=5.97. } p<0.001\end{array}$ \\
\hline $\begin{array}{l}\text { SBP }(\mathbf{m m H g}) \\
\text { Mean } \pm \text { SD } \\
\text { Range }\end{array}$ & $\begin{array}{l}135 \pm 6.74 \\
(120-1+0)\end{array}$ & $\begin{array}{l}165 \pm 6.74 \\
(160-180)\end{array}$ & $\begin{array}{c}110.83 \pm 6.74 \\
(100-120)\end{array}$ & $\begin{array}{c}125.83 \pm 5.14 \\
(120-130)\end{array}$ & $\begin{array}{l}\text { (A) vs }(B) . t=10.9, p<0.001 \\
\text { (C) vs (D). t=3.01, } P<0.001\end{array}$ \\
\hline $\begin{array}{l}\text { MBP }(\mathbf{m m H} \mathbf{g}) \\
\text { Mean } \pm S D \\
\text { Range }\end{array}$ & $\begin{array}{c}101.38 \pm 4.37 \\
(93.33-106.67)\end{array}$ & $\begin{array}{c}123.88 \pm 3.97 \\
(120-130)\end{array}$ & $\begin{array}{c}82.5 \pm 6.05 \\
(73.33-93.33)\end{array}$ & $\begin{array}{l}95.55 \pm 3.84 \\
(86.67-100)\end{array}$ & $\begin{array}{l}\text { (A) vs }(B), t=13.18, p<1) .001 \\
\text { (C) vs (D). } t=6.30 . p<0.001\end{array}$ \\
\hline $\begin{array}{l}\text { HTN duration } \\
\text { Mean+SD } \\
\text { Range }\end{array}$ & $\cdot$ & $\begin{array}{l}9 \pm 1.85 \\
(7-13)\end{array}$ & - & $\cdot$ & $\cdot$ \\
\hline
\end{tabular}

Table (II): Echocardiographic parameters of the studied groups

\begin{tabular}{|c|c|c|c|c|c|}
\hline & Group (A) & Group (B) & Group (C) & Group (D) & Test of significance \\
\hline $\begin{array}{l}\text { EDD }(\mathrm{cm}) \\
\text { Mean } \pm S D \\
\text { Range }\end{array}$ & $\begin{array}{l}+.91 \pm 0.25 \\
(+.3-5.2)\end{array}$ & $\begin{array}{l}4.93 \pm 0.24 \\
(4.4-5.4)\end{array}$ & $\begin{array}{l}+.85 \pm 1.1 \\
(3.9-5.1)\end{array}$ & $\begin{array}{c}+.38 \pm 0 .+4 \\
(3.8-5)\end{array}$ & $\begin{array}{l}\text { (A) vs }(B), t=0.16 . p=0.87 \\
\text { (C) vs (D), } t=1.36, p=0.18\end{array}$ \\
\hline $\begin{array}{l}\text { ESD } \\
\text { Mean } \pm \text { SD } \\
\text { Range }\end{array}$ & $\begin{array}{l}3.17 \pm 0.23 \\
(2.9-3.9)\end{array}$ & $\begin{array}{l}3.12 \pm 0.44 \\
(2.1-3.8)\end{array}$ & $\begin{array}{l}2.69 \pm 0.48 \\
(2.1-3.2)\end{array}$ & $\begin{array}{l}2.82 \pm 0.48 \\
(2.1-3.7)\end{array}$ & $\begin{array}{l}\text { (A) vs (B), t=0.35. } p=0.73 \\
\text { (C) vs (D), t }=0.67, p=0.50\end{array}$ \\
\hline $\begin{array}{l}\text { IVS } \\
\text { Mean } \pm S D \\
\text { Range }\end{array}$ & $\begin{array}{l}1.15 \pm 0.116 \\
(0.90-1.3)\end{array}$ & $\begin{array}{l}1 .+8 \pm+1.126 \\
(1.3-1.7)\end{array}$ & $\begin{array}{c}1.008 \pm 0.099 \\
(0.9-1.2)\end{array}$ & $\begin{array}{c}0.95+0.108 \\
(0.8-1.1)\end{array}$ & $\begin{array}{l}\text { (A) vs }(B), t=6.7, p<0.001 \\
\text { (C) vs (D). t }=1.37 . p=0.18\end{array}$ \\
\hline $\begin{array}{l}\text { PWT } \\
\text { Mean } \pm S D \\
\text { Range }\end{array}$ & $\begin{array}{c}0.966 \pm 0.137 \\
(0.8-1.2)\end{array}$ & $\begin{array}{l}1.21 \pm 0.08 \\
(1.1-1.3)\end{array}$ & $\begin{array}{c}0.85 \pm 0.079 \\
(0.7-1) \\
\end{array}$ & $\begin{array}{c}0.85 \pm 0.079 \\
(0.8-1)\end{array}$ & $\begin{array}{c}\text { (A) vs }(B), t=5.39, p<0.001 \\
\text { (C) vs (D). } t=0 . P=1\end{array}$ \\
\hline $\begin{array}{l}\text { Diastolic } \\
\text { dysfunction } \\
\text { +ve (\%) } \\
\text {-ve (\%) }\end{array}$ & $\begin{array}{l}5(+1.7) \\
7(58.3)\end{array}$ & $\begin{array}{c}12(100) \\
.\end{array}$ & $12(100)$ & $12(100)$ & $\begin{array}{c}\text { Chi-square } X^{2}=32.7 . \\
P<0.001\end{array}$ \\
\hline
\end{tabular}


FLOW MEDIATED DILATATION IN HYPERTENSIVE etc...

Table (III): Brachial diameter and FMD in the studied groups

\begin{tabular}{|c|c|c|c|c|}
\hline & $\begin{array}{c}\text { Brachial diameter } \\
\text { (cm) "Before" } \\
\text { Mean } \pm \text { SD } \\
\text { Range }\end{array}$ & $\begin{array}{c}\text { Brachial diameter } \\
\text { (cm) "After" } \\
\text { Mean } \pm S D \\
\text { Range }\end{array}$ & $\begin{array}{l}\% \text { of change in } \\
\text { brachial diameter } \\
\text { Mean } \pm S D \\
\text { Range }\end{array}$ & $\begin{array}{c}\text { Test of } \\
\text { significance } \\
\text { Before (vs) After }\end{array}$ \\
\hline Group (A) & $\begin{array}{l}0.37 \pm 0.032 \\
(0.31-0.41)\end{array}$ & $\begin{array}{l}0 .+19 \pm 0.032 \\
(0.36-0 .+6)\end{array}$ & $\begin{array}{c}0.113 \pm 0.017 \\
(0.10-0.16)\end{array}$ & $\begin{array}{c}t=16.1 \\
P<0.001\end{array}$ \\
\hline Group (B) & $\begin{array}{l}0.41 \pm 0.012 \\
(0.39-0 .+3)\end{array}$ & $\begin{array}{l}0 .+32 \pm 0.016 \\
(0 .+1-0 .+5)\end{array}$ & $\begin{array}{c}0.055 \pm 0.035 \\
(0-0.10)\end{array}$ & $\begin{array}{c}t=1.95 \\
p=0.053\end{array}$ \\
\hline Group (C) & $\begin{array}{c}0.335 \pm 0.027 \\
(0.30-0.38)\end{array}$ & $\begin{array}{c}0.399 \pm 0.0231 \\
(0.37-0.44)\end{array}$ & $\begin{array}{l}0.19+0.039 \\
(0.1+-0.27)\end{array}$ & $\begin{array}{l}t=12.1 \\
P<0.001\end{array}$ \\
\hline Group (D) & $\begin{array}{c}0.373 \pm 0.038 \\
(0.30-0 .+1)\end{array}$ & $\begin{array}{l}0.41 \pm 0.035 \\
(0.3+-0.45)\end{array}$ & $\begin{array}{l}0.109 \pm 0.019 \\
(0.07-0.15)\end{array}$ & $\begin{array}{l}t=16.1 \\
P<0.001\end{array}$ \\
\hline $\begin{array}{l}\text { Test of sig } \\
\text { between groups } \\
\text { (A) Vs (B) } \\
\text { (C) vs (D) }\end{array}$ & $\begin{array}{l}t=3.35 . P=0.003 \\
t=2.45 . P=0.009\end{array}$ & $\begin{array}{l}t=1.28 . P=0.21 \\
t=0.92 . P=0.36\end{array}$ & $\begin{array}{l}t=5.81 . P<0.001 \\
t=6.45 . P<0.001\end{array}$ & \\
\hline
\end{tabular}

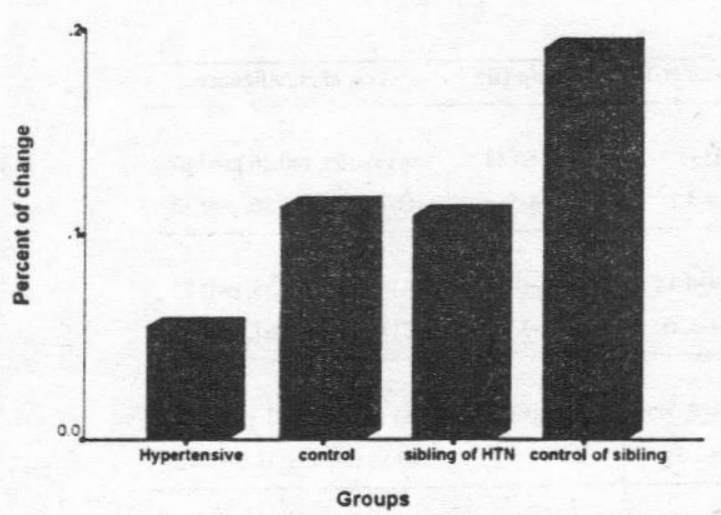

Fig. (1) : Percentage of change in brachial artery diameter in the studied groups.

Vol. 33, No. 3 \& 4 July. \& Oct, 2002

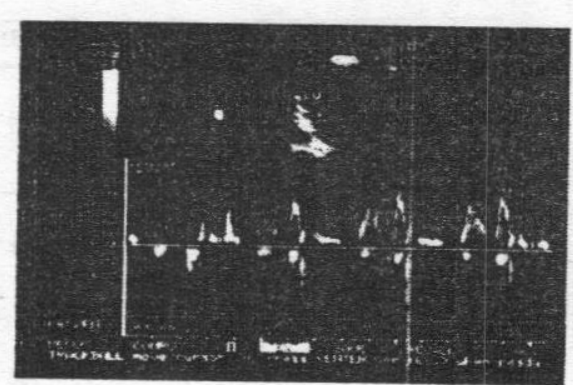

Fig. (2) : Pulsed wave Doppler of mitral valve showing diastolic dysfunction of left ventricle (reversed $E / A$ ratio) 


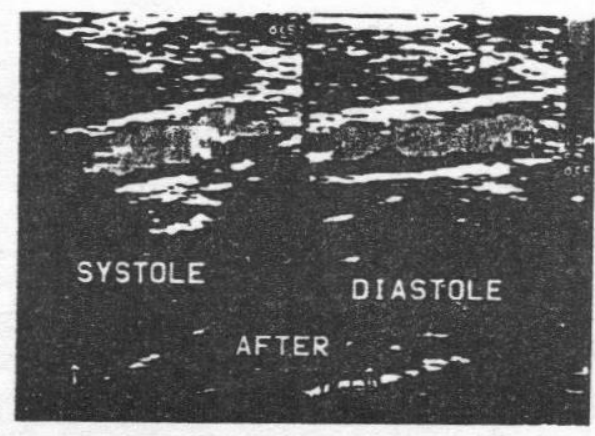

Fig. (3) : Color Doppler flow mapping of the right brachial artery in systole and diastole showing the change of the caliber of the artery.

\section{DISCUSSION}

Our choice of brachial artery to evaluate peripheral blood flow represent a technical advantage, it is easy to palpate and to perform the examination in fully clothed patient.

The interesting finding in this respect that the systolic and diastolic blood pressure show a highly significant elevation in the group of hypertensive sibling when compared to their control subjects.

Also the mean blood pressure in

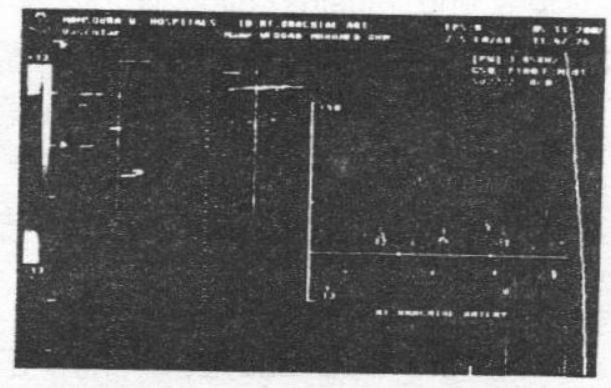

Fig. (4) : Doppler flow imaging of the right brachial artery showing the normal triphasic wave form pattern.

the sibling of essential hypertension shows a highly significant elevation $(95.5 \pm 3.8 \mathrm{mmHg}$ ) when compared to their control $(82.5 \pm 6.05 \mathrm{mmHg})$ indicating that the systolic and diastolic and as a consequence, The mean blood pressure although in the normal range was higher in the sibling of hypertensive subjects when compared to control group (table I).

The EDD and ESD show a nonsignificant difference when comparing the hypertensive patient with their control and this could be explained by

MANSOURA MEDICAL JOURNAL 
selection of the compensated subjects and by the old age of the two groups because elderly normotensives may show left ventricular hypertrophy and impaired diastolic relaxation (9). Our results are concide with this study as evidenced by presence of diastolic dysfunction in the normotensive elderly in 5 out of 12 subjects with $\%$ of $41.7 \%$ (table II).

Also the EDD and ESD show a non significant differences between the sibling of hypertensive patients and their control because both groups are young and are normotensive and also this explain the non significant changes in IVS and PWT in both groups.

The IVS and PWT show a highly significant increase in patients with essential hypertension when compared to their normotensive control and this is simply due to concentric hypertrophy which caused by elevated systolic and diastolic blood pressure.

Diastolic dysfunction occurring in all patients with essential hypertension $(100 \%)$ and observed in 5 out of 12 control subjects $(41.7 \%)$ explained by old age of this group $(54.2 \pm 2.4$ years) due to effect of aging on the diastolic function of left ventricle (table I \& II).

\section{Ultrasonographic data:-}

In the present study, we show a deterioration of endotheliumdependent dilatation of the brachial artery in patients with essential hypertension but without overt atherosclerotic diseases and this finding confirms previous reports that show that acetylcholine-induced vasodilator response, which requires an intact endothelium was impaired in patients with essential hypertension (10).

In our study, we assessed endothelial function by measurement of the change in diameter of the brachial artery during reactive hyperemia, which is not a resistant artery, in comparison to control. In contrast, previous studies measured forearm blood flow by plethysmography which reflects changes in the resistance of microcirculation (11). There for our study suggests that in essential hypertension there is endothelial dysfunction in large arteries in away similar to what occur in small resistance arteries.

In previous studies, the diameter of the brachial artery was significantly 
increase and the velocity was slightly reduced and this finding concide with our result that show increase basal brachial diameter in hypertensive patients $(0.419 \pm 0.03 \mathrm{~cm})$ versus $(0.37 \pm 0.032 \mathrm{~cm})$ in their control group. Also the basal diameter of the sibling of hypertension is higher than their control group $(0.373 \pm 0.038)$ versus $(0.325 \pm 0.027)$.

Flow mediated dilatation (FMD) which is the change in the brachial diameter during reactive hyperemia which is an indication about endothelial function is impaired in the hypertensive group which show minimal difference in the diameter of brachial artery before and after occlusion. The percentage of change was $(0.55 \pm 0.035)$ with $p$ value $=0.053$ for this group while the percentage of change in brachial diameter in their control group was $(0.113 \pm 0.017)$ with $p$ value $P<0.001$ for this group.

When comparing the two groups there was a highly significant increase in the brachial diameter in the control group versus the hypertensive group with $P<0.001$. These finding implies that the FMD is impaired in patients with essential hypertension when compared to control. This finding is in agree with Schmieder et al. (1997) (12), who suggest impaired FMD in radial artery in patient with essential hypertension. These result are in contrary to Laurent et al. (1990) (6), who failed to demonstrate impaired FMD in hypertensive patients. Probably due to the short period of occlusion of the investigated arm (2 minutes only).

The important and interesting finding of our study that in the sibling of patients with essential hypertension the percentage of change of the brachial diameter is less than the control group $(0.109 \pm 0.019)$ versus $(0.19 \pm 0.039)$. Although both groups show a highly significant increase when comparing the diameter of brachial artery before and after occlusion with $P<0.001$. the percentage of change in hypertensive sibling shows a highly significant increase when compared to their control group with $\mathrm{P}<0.001$.

This finding indicate that FMD of brachial artery is impaired in the normotensive sibling of patients with essential hypertension.

Conclusion:-

Patients with essential hypertenMANSOURA MEDICAL JOURNAL 
sion had decreased FMD of the brachial artery during reactive hyperemia, a finding which also present in their sibling although in normotensive range.

These findings indicate that hypertension is related to endothelial dysfunction and this endothelial dysfunction precede the clinical manifestation of hypertension and so could be detected in the sibling of patients with essential hypertension and this results points to the value of FMD as an early non-invasive predictor of endothelial dysfunction before appearance of its clinical manifestations.

\section{REFERENCES}

1- Ruschitzka F, Corti R, Noll G, Luscher TF (1999) : A rationale for treatment of endothelial dysfunction in hypertension. J Hypertens 17 (suppl. 1); 25.

2- Muiesan ML, Salvetti M, Monteduro C et al. (1999) : Effect of treatment on flowdependent vasodilatation of brachial artery in essential hypertension. Hypertension; 33:575.

Vol. 33, No. 3 \& 4 July. \& Oct, 2002
3- Flavahan NA. (1992) : Atherosclerosis or lipoprotein-induced endothelial dysfunction: potential mechanisms underlying reduction in EDRF/nitric oxide activity. Criculation; 85:1927-38.

4- Celermajer DS, Sorensen KE, Gooch VM et al. (1992) : Non-invasive detection of endothelial dysfunction in children and adult at risk of atherosclerosis. Lancet; 340:1111-5.

5- Liyama K, Nagano M, Yo Y, et al. (1996) : Impaired endothelial function with essential hypertension assessed by ultrasonography. Am Heart J; 132:779-82.

6- Laurent S, Lacolley P, Brunel P, et al. (1990) : Flowdependent vasodilatation of the brachial artery in essential hypertension. Am J Physiol; 258:H1004-H11.

7- McVeigh GE, Brennan GM, Johnston GD, McDermott BJ, McGrath LT, Henry WR, et al. (1992) : Impaired 
endothelial-dependent and independent vasodilatation in patients with type 2 diabetes. Diabetologia; 35 : 771-6.

8- Pohl U, Holtz J, Busse R, Bassonge E. (1986) : crucial role of endothelium in the vasodilator response to increased flow in vivo. Hypertension; 8:37-44.

9- Grossman W (1990) : Cardiac hypertrophy: useful adaptation or pathologic process? Am J Med; 69:576-84.

10- Panza JA, Casino PR, Kileoye CM, Quyyumi AA. (1993) : Role of endothelium-derived nitric oxide in the abnormal endothelium- dependent vascular relaxation of patients with essential hypertension. Circulation; 87 : 1468-74.

11- Calver A, Collier J, Moneado S, Vallance P. (1992) : Effect of local intra-arterial $N^{6}$. monomethyl -L-arginine in patients with hypertension. The nitric oxide dilator mechanism appears abnormal. $\mathrm{J}$ Hypertens; 10:1052-31.

12- Schmieder RE, Weihprecht $H$, Schobel H, et al. (1997): Is endothelial function of the radial artery altered in human essential hypertension? Am J Hypertens; 10:323-31. 
